\title{
Comparisons of Glucose and Lipid Metabolism in Rats Fed Diacylglycerol and Triacylglycerol Oils
}

\author{
Tomomi Sugimoto, Tomoe Kimura, Hitomi Fukuda and Nobuko IrItani* \\ Faculty of Human and Culture Studies, Tezukayama Gakuin University, \\ 4-2-2 Harumidai, Sakai, Osaka 590-0113, Japan
}

(Received October 16, 2002)

\begin{abstract}
Summary The effects of dietary 1,3-diacylglycerol-rich oil (DG oil) on biochemical findings related to glucose and lipid metabolisms were investigated in comparison with triacylglycerol oil (TG oil) in normal rats. Young ( 7 wk-old) and old ( 8 mo-old) rats were fed a synthetic diet containing $10 \%$ (by weight) DG or TG oil for $1,4,8$, or $12 \mathrm{wk}$. The body weights, epididymal and perirenal adipose tissue weights, and feed efficiency were not significantly different in the dietary oil groups during any feeding period. The plasma and liver triacylglycerol concentrations were not different in the dietary groups, except that the plasma triacylglycerol concentrations were rather lower only in the portal vein of rats fed DG oil. The plasma glucose and free fatty acid concentrations were significantly higher in rats fed DG oil as compared to TG oil. In the old rats fed DG oil for $8 \mathrm{wk}$, the fasted plasma glucose and insulin concentrations were elevated and glucose intolerance was observed. The insulin receptor expression was not different due to dietary oil, but was markedly reduced with aging. Thus, the anti-obesity and lipid-lowering effects of dietary DG oil were not found. Moreover, it appeared that the glucose intolerance might be induced by dietary DG oil, particularly in the old rats.
\end{abstract}

Key Words dietary diacylglycerols, triacylglycerol levels, free fatty acids, glucose, insulin

It has been reported that dietary diacylglycerol oil (DG oil) apparently suppresses fat accumulation as compared to triacylglycerol oil (TG oil) in humans and rats, and possibly reduces the risk of diseases associated with visceral fat obesity (1-4). Intragastric infusion of an emulsion containing DG oil reduced the serum triacylglycerol levels as compared to TG oil infusion in rats and markedly elevated portal vein free fatty acid (1). 1Monoacylglycerols, rarely found in the digestion of TG oil in the intestine, were found in the digestion of DG oil. Energy values of the DG and TG oils measured by bomb calorimeter were very similar, and the apparent digestibilities of the DG and TG oils were similar (96\%) (5). Thus, it was hypothesized that the reduction of fat accumulation by dietary DG oil is caused by different metabolic fates after absorption into the gastrointestinal epithelial cells.

However, increased plasma free fatty acid concentrations have commonly been associated with impaired insulin-mediated glucose uptake and many insulin-resistant states $(6,7)$. Fatty acid-rich medium reduced insulin receptor tyrosin kinase activity in rat hepatoma cells (8). Dresner et al. (9) concluded that increased concentrations of plasma free fatty acids induce insulin resistance in humans through the inhibition of glucose transport activity. Therefore, extensive physiological and nutritional studies on DG oil are required before the synthetic oil can be recommended for use in daily diets.

* To whom correspondence should be addressed.

E-mail: iritani@hcs.tezuka-gu.ac.jp
The synthetic oil product containing a high level of DG oil (55\% 1,3-DG, 25\% 1,2-DG, and 20\% TG) (4) is now commercially available. Natural edible oil contains 1,2-DG and 1,3-DG as minor components. 1,2-DG is converted to 1,3-DG by acyl migration in edible oils (10). 1,2-DG is an intermediate of triacylglycerol digestion in the intestine. However, further studies on the health safety of DG oil (containing such a high level of DG, $80 \%$ in total) should be also investigated. Thus, we have investigated the effects of DG oil ingestion on glucose and lipid metabolism as compared to TG oil; particularly, the influence of increased plasma free fatty acids on insulin resistance in rats.

\section{MATERIALS AND METHODS}

Materials. $\quad\left[\alpha^{32} \mathrm{P}\right] \mathrm{dCTP}(111 \mathrm{TBq} / \mathrm{mmol})$ was purchased from ICN Pharmaceuticals, Inc. (Costa Mesa, CA, USA). [ $\left.{ }^{125} \mathrm{I}\right]$ Insulin $(74 \mathrm{TBq} / \mathrm{mmol})$ was purchased from Amersham (Buckinghamshire, UK). The nylon filter (Hybond N) was purchased from Amersham and the insulin assay kit was obtained from Eiken Chemical Company (Tokyo, Japan). Most other reagents were obtained from Wako Pure Chemical Industries, Ltd. (Osaka, Japan) and from Sigma (St. Louis, MO, USA).

For dietary fat, Nisshin salad oil (a mixture of rapeseed and soybean oils, Nisshin Oillio Co., Tokyo) was used as the TG oil, and Kao Econa (Kao Co., Tokyo, Japan) was used as the DG oil. The DG oil used in the present experiment contained 53.8\% 1,3-DG; $27.6 \%$ 1,2-DG, and $18.6 \% \mathrm{TG}$.

Animals. Male Wistar rats (Japan SLC Co., 
Hamamatsu, Japan), 7 wk-old or 8 mo-old, fed on a commercially available non-purified diet (No. MF, Oriental Shiryou Co., Osaka, Japan) were fed a 10\% DG oil or TG oil diet for $1,4,8$, and $12 \mathrm{wk}$. The rats $7 \mathrm{wk}-$ old or 8 mo-old were given free access to water and fed a stock diet before being used for the experiment.

The composition of the diet was $(\mathrm{g} / 100 \mathrm{~g})$ : sucrose, 56.3; casein, 20; DG or TG oil, 10; cellulose, 9.5; salt mixture (11), 4.0; choline chloride, 0.1; and vitamin mixture (11), 0.1. The major fatty acid composition of the DG oil used was $(\mathrm{g} / 100 \mathrm{~g}$ total fatty acids): $16: 0$, $4.57 ; 18: 0,1.62 ; 18: 1,39.8 ; 18: 2,49.9 ; 18: 3,4.19$. Those of TG oil were $(\mathrm{g} / 100 \mathrm{~g}$ total fatty acids): 16:0, 8.46; 18:0, 2.59; 18:1, 49.3; 18:2, 34.5; 18:3, 5.15. Rats were individually housed in wire-bottomed cages in a temperature-controlled room $\left(24^{\circ} \mathrm{C}\right)$ under an automatic lighting schedule (8:00 to $20: 00 \mathrm{~h})$. The rats had free access to water and were each fed equal energy-supplemented DG or TG oil diets per body weight (bw) per day. The amount of diet consumed by each rat was measured at 17:00 h every day, and based on the measurement, the expected amount of diet consumed was given for the following day.

The rats were sacrificed (without being food deprived) between 9:00 and 10:00 h. They were decapitated after blood was taken from the portal vein and inferior vena cava using a heparinized syringe while under diethyl ether anesthesia. Plasma was obtained by centrifugation of heparinized blood at $4^{\circ} \mathrm{C}$ for $20 \mathrm{~min}$ at $1,200 \times \mathrm{g}$. The plasma concentrations of glucose, insulin, free fatty acids, ketone bodies, and triacylglycerols were measured. The rats, food deprived for $16 \mathrm{~h}$, similarly had plasma taken from the tail vein during the 4 th and 8 th week of feeding and the concentrations were measured. The rats were refed on the previous diets and sacrificed for measurement during the 8 th and 12 th week of feeding, respectively. The tissues to be used were immediately removed, weighed and frozen in liquid nitrogen, and stored at $-80^{\circ} \mathrm{C}$ until being used to measure the relative mRNA abundances by dot or Northern blot hybridization analysis. An aliquot of liver was quickly removed and homogenized with three volumes of $0.25 \mathrm{~mol} / \mathrm{L}$ sucrose. The $10,000 \times g$ supernatant of the homogenate was centrifuged at $105,000 \times g$ for $45 \mathrm{~min}$ (Model L5, Type 40 rotor, Beckman Instruments, Palo Alto, CA, USA). The $105,000 \times g$ supernatant was used for the measurement of lipogenic enzyme activities. Care and treatment of experimental animals were in accordance with the Guide for the Care and Use of Laboratory Animals (12).

The oral glucose tolerance test during the 3rd and 7 th week of feeding was done $1 \mathrm{wk}$ before the rats were sacrificed. Rats were given a $400 \mathrm{~g} / \mathrm{L}$ glucose solution ( $3 \mathrm{~g}$ glucose/kg bw) by stomach tube after being deprived of food for $16 \mathrm{~h}$. Blood was taken with a heparinized syringe from the tail vein.

Dot blot and Northern blot hybridization assays. Human insulin receptor cDNA (13) was a generous gift from Professor Y. Ebina (Institute for Enzyme Research, University of Tokushima, Japan). The genomic clone of rat rRNA was obtained from the Japanese Cancer Research Resources Bank (Mishima, Japan). A BamHI/EcoRI fragment of about $1 \mathrm{~kb}$ of the clone was isolated and used as a probe for $18 \mathrm{~S}$ rRNA. Total RNA was isolated from liver and epididymal adipose tissues by acid guanidium thiocyanate-phenol-chloroform extraction (14). To measure the relative mRNA abundances of insulin receptors of the total RNA (20$50 \mu \mathrm{g}$ ), was denatured with formamide, spotted on a nylon filter, and then radiated with ultraviolet light for $5 \mathrm{~min}$. The filter was prehybridized and then hybridized with ${ }^{32} \mathrm{P}$-labeled cDNA as described previously (15). Relative densities of the hybridization signals were determined by scanning the autoradiograms at $525 \mathrm{~nm}$ and normalized to the values of $18 \mathrm{~S}$ rRNA. The relative mRNA abundances were measured by the dot blot hybridization method, and many of them were confirmed by Northern blot analysis.

Northern blot analysis of RNA was performed as described by Gonzales and Kasper (16). Total RNA was denatured and electrophoresed on a $1.0 \%$ agarose gel containing $2.2 \mathrm{~mol} / \mathrm{L}$ formaldehyde. The gel was blotted onto a nylon filter according to Thomas (17). Details of prehybridization, hybridization, and autoradiography were as described previously (15). The autoradiograms of Northern blot analysis of insulin receptors were shown in our previous report (18).

Preparation and insulin binding assay of adipocytes. Isolated epididymal fat cells were prepared by shaking adipose tissue at $37^{\circ} \mathrm{C}$ for $60 \mathrm{~min}$ in Krebs-Ringer bicarbonate buffer containing collagenase $(2 \mathrm{~g} / \mathrm{L})$ and albu$\min (30 \mathrm{~g} / \mathrm{L})$, according to the method of Rodbell (19). Adipocytes were incubated in Krebs Riger buffer (50 g/L BSA, pH 7.4) containing [ $\left.{ }^{125} \mathrm{I}\right]$-labeled insulin and varying concentrations of unlabeled insulin for $45 \mathrm{~min}$ at $25^{\circ} \mathrm{C}$. Incubations were terminated by the oil flotation method, and the incorporation of radio-labeled insulin by adipocytes was measured using a gamma counter $(20,21)$.

Preparation and insulin binding assay of liver. Insulin receptors were purified from livers using a wheat germagarose column according to the method of Kadowaki et al. (22). The lectin-purified insulin receptors were incubated with $\left[{ }^{125} \mathrm{I}\right]$-labeled insulin at $4^{\circ} \mathrm{C}$ for $16 \mathrm{~h}$ in the presence of varying concentrations of unlabeled insulin (23). With human $\gamma$ globulin as the carrier protein, receptor-bound insulin was precipitated with polyethylene glycol (23).

Analyses. Plasma glucose concentrations were determined by the glucose-oxidase method (24). Plasma insulin concentrations were measured by a two-antibody system radio-immunoassay according to the method of Morgan and Lazarow (25). Plasma and liver triacylglycerol concentrations were measured by the method of Fletcher (26). Plasma free fatty acid and total ketone bodies were measured by the methods of Kushiro and Fukui (27) and Harano et al. (28), respectively.

Acetyl-CoA carboxylase (EC 6.4.1.2) activity was assayed by the $\mathrm{H}^{14} \mathrm{CO}_{3}^{-}$-fixation method (29). Fatty acid synthase (EC 2.3.1.85) activity was assayed according 
to Hsu et al. (30). The enzyme activities in the supernatant of the liver homogenates are shown as $\mathrm{mU} / \mathrm{mg}$ protein, when $1 \mathrm{mU}$ is the amount catalyzing the formation of nanomoles product $/ \mathrm{min}$ at $37^{\circ} \mathrm{C}$. Protein was determined by the method of Lowry et al. (31).

Statistical analysis. Two- or three-way ANOVA was followed by inspection of all differences between pairs of means by using the least significant difference test (32). $t$-Test was tried between DG and TG oil diets. Differences were considered significant at $p<0.05$.

\section{RESULTS}

\section{Animal profiles}

The young and old rats ( 7 wk-old and 8 mo-old at the start of feeding experimental diets) were fed a DG or TG oil diet for $1,4,8$, and $12 \mathrm{wk}$. The body weights, liver weights/100 $\mathrm{g}$ bw, epididymal and perirenal adipose tissue weights/100 g bw, and feed efficiency (g bw gain/100 g food consumption) were not significantly different due to the dietary fat type at any feeding period in the young and old rats. Therefore, data for rats fed the fat diets for $8 \mathrm{wk}$ only were shown in Table 1 . Spontaneous food consumption tended to be less in the DG group than in the TG group. However, the differences of average food consumption were controlled within $5 \%$ in the dietary oil groups.

Effects of dietary fat types on plasma glucose and insulin concentrations

The plasma glucose concentrations were significantly higher in the portal vein and inferior vena cava of the
Table 1. Effects of dietary fat types on body weights, epididymal and perirenal adipose tissue weights, and feed efficiency in rats fed DG or TG oil diet for $8 \mathrm{wk} .^{1}$

\begin{tabular}{lcc}
\hline Dietary fat & Young & Old \\
\hline Body weight $(\mathrm{g})$ & & \\
DG & $461 \pm 16.0$ & $593 \pm 26.9$ \\
TG & $472 \pm 12.7$ & $613 \pm 21.2$ \\
Liver weight $(\mathrm{g} / 100 \mathrm{~g}$ bw) & \\
DG & $3.48 \pm 0.14$ & $3.23 \pm 0.15$ \\
TG & $3.85 \pm 0.10$ & $3.05 \pm 0.05$ \\
Epididymal adipose tissue weight $(\mathrm{g} / 100 \mathrm{~g} \mathrm{bw})$ \\
DG & $1.58 \pm 0.14$ & $1.61 \pm 0.21$ \\
TG & $1.65 \pm 0.14$ & $1.67 \pm 0.11$ \\
Perirenal adipose tissue weight $(\mathrm{g} / 100 \mathrm{~g}$ bw) & \\
DG & $2.19 \pm 0.60$ & $3.42 \pm 0.04$ \\
TG & $2.26 \pm 0.34$ & $3.36 \pm 0.31$ \\
Feed efficiency (bw $\mathrm{g} / 100 \mathrm{~g}$ diet $)$ & \\
DG & $21.8 \pm 1.60$ & $4.38 \pm 0.12$ \\
TG & $21.8 \pm 0.94$ & $4.65 \pm 0.31$ \\
\hline
\end{tabular}

${ }^{1}$ Data are presented as means $\pm \mathrm{SE}, n=6$. The young and old rats (7 wk-old and 8 mo-old, respectively) were paired-fed DG and TG oil diets for $1,4,8$, and $12 \mathrm{wk}$, as described in Materials and Methods. As no significant differences due to dietary fat in body weights, epididymal and perirenal adipose tissue weights, and feed efficiency were found, data for rats fed the diets for $8 \mathrm{wk}$ only are shown above. The feed efficiency was calculated as body weight gain (g)/food consumption (100 g) for feeding period.

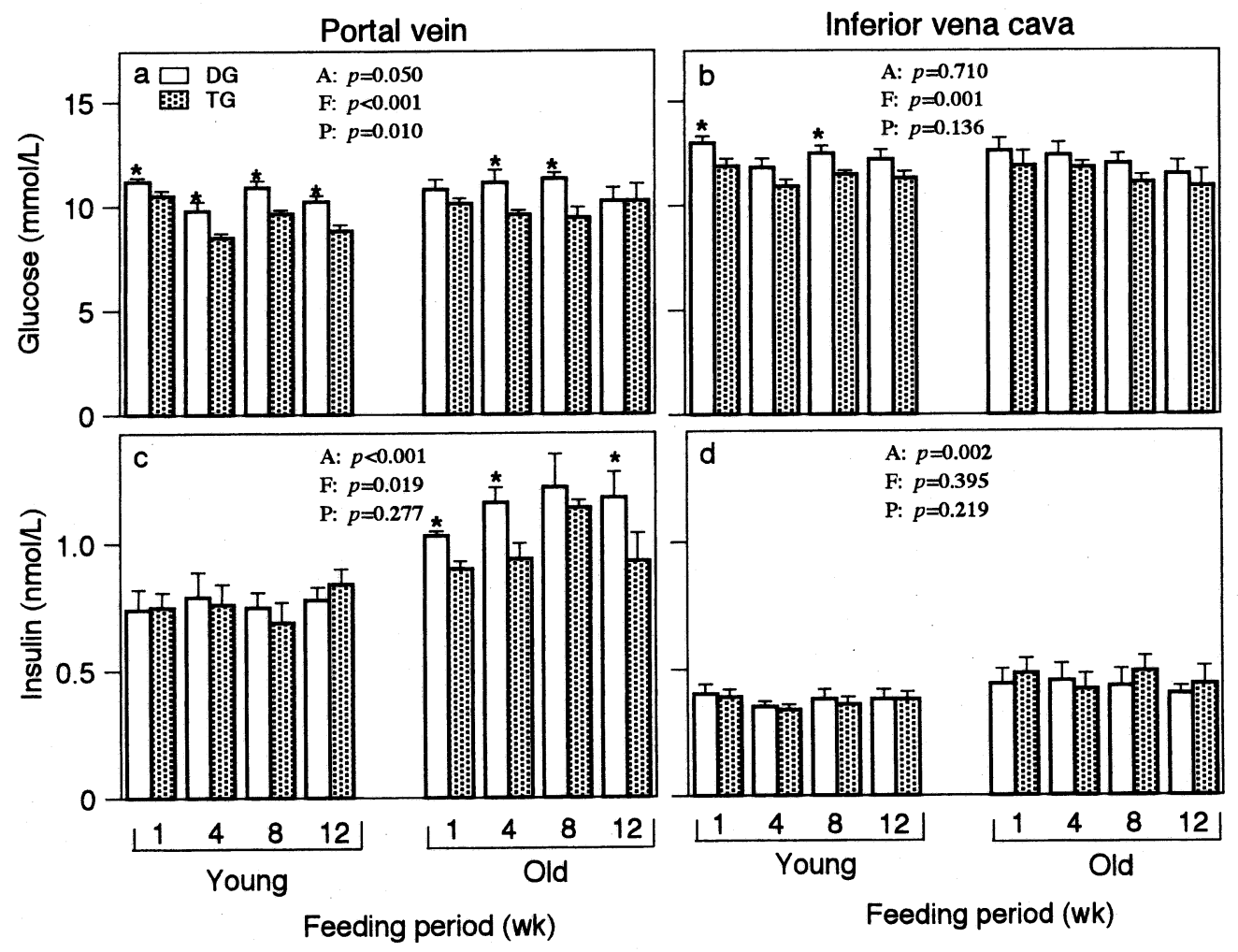

Fig. 1. Effects of dietary fat types on plasma glucose and insulin concentrations in the portal vein and inferior vena cava of young and old rats. The rats were fed diets containing DG oil or TG oil for 1, 4, 8, or 12 wk. Panels a and b show the plasma glucose concentrations of portal vein and inferior vena cava, respectively, and panels $\mathrm{c}$ and $\mathrm{d}$, the corresponding insulin concentrations, respectively. Data are means \pm SE, $n=6$. Three-way ANOVA in each panel, A, aging main effect; $F$, dietary fat main effect; $\mathrm{P}$, feeding period main effect. * Significantly different from TG oil group $(t$-test). 
DG oil groups of the young and old rats as compared to the TG oil groups (Fig. 1). The glucose concentrations were more significantly elevated by DG oil in the portal vein than in the inferior vena cava. The glucose concentrations in the TG oil group were reduced with feeding period, whereas those in the DG oil were not. No effects of aging were observed. The plasma insulin concentrations in the portal vein were not different in the young rats, but were significantly elevated by DG oil in the old rats. However, the insulin concentrations in the inferior vena cava did not show any difference due to dietary oil. The plasma insulin concentrations in both veins were higher in the old rats than in the young, particularly in the portal vein.

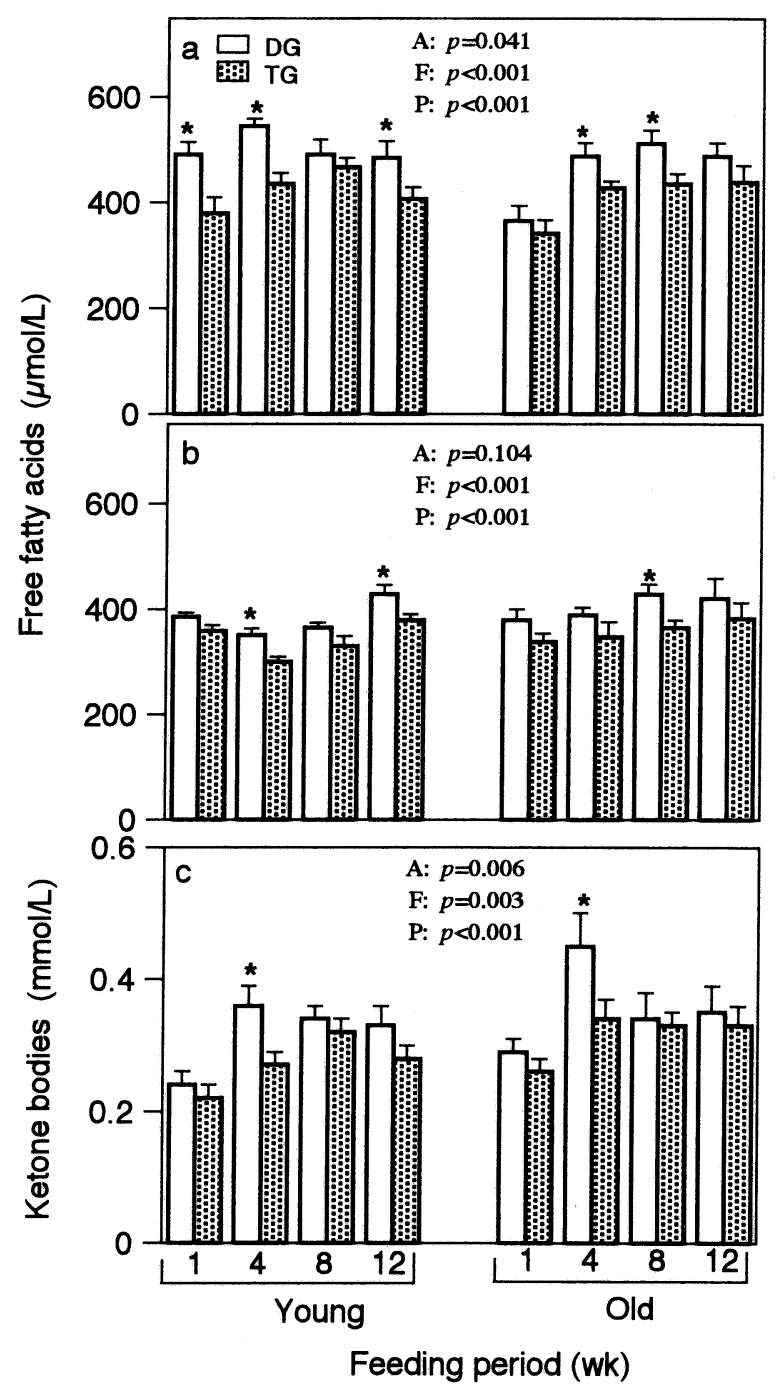

Fig. 2. Effects of dietary fat types on plasma free fatty acid and ketone body concentrations in rats of young and old rats. The plasma free fatty acid concentrations in portal vein (panel a) and inferior vena cava (panel b), and ketone body concentrations in inferior vena cava (panel c) of the same rats to Fig. 1 are shown. Data are means \pm SE, $n=6$. Three-way ANOVA in each panel, A, aging main effect; F, dietary fat main effect; $\mathrm{P}$, feeding period main effect. * Significantly different from TG oil group ( $t$-test).
Effects of dietary fat types on plasma free fatty acid and ketone body concentrations

Plasma free fatty acid concentrations were significantly elevated $(p<0.001)$ by dietary DG oil as compared to TG oil in both the portal vein and inferior vena cava of the young and old rats (Fig. 2). These elevations due to DG oil were more markedly higher in the portal vein. The free fatty acid concentrations were elevated with feeding period. Plasma total ketone body concentrations in the inferior vena cava were significantly higher in rats fed DG oil than in those fed TG oil. The concentrations were particularly elevated by dietary DG oil at $4 \mathrm{wk}$ after feeding in both young and old rats (Fig. 2 ). The ketone body concentrations were elevated with feeding period and were higher in the old rats than in the young.

Effects of dietary fat types on triacylglycerol concentrations and lipogenic enzyme activities

Plasma triacylglycerol concentrations in the inferior

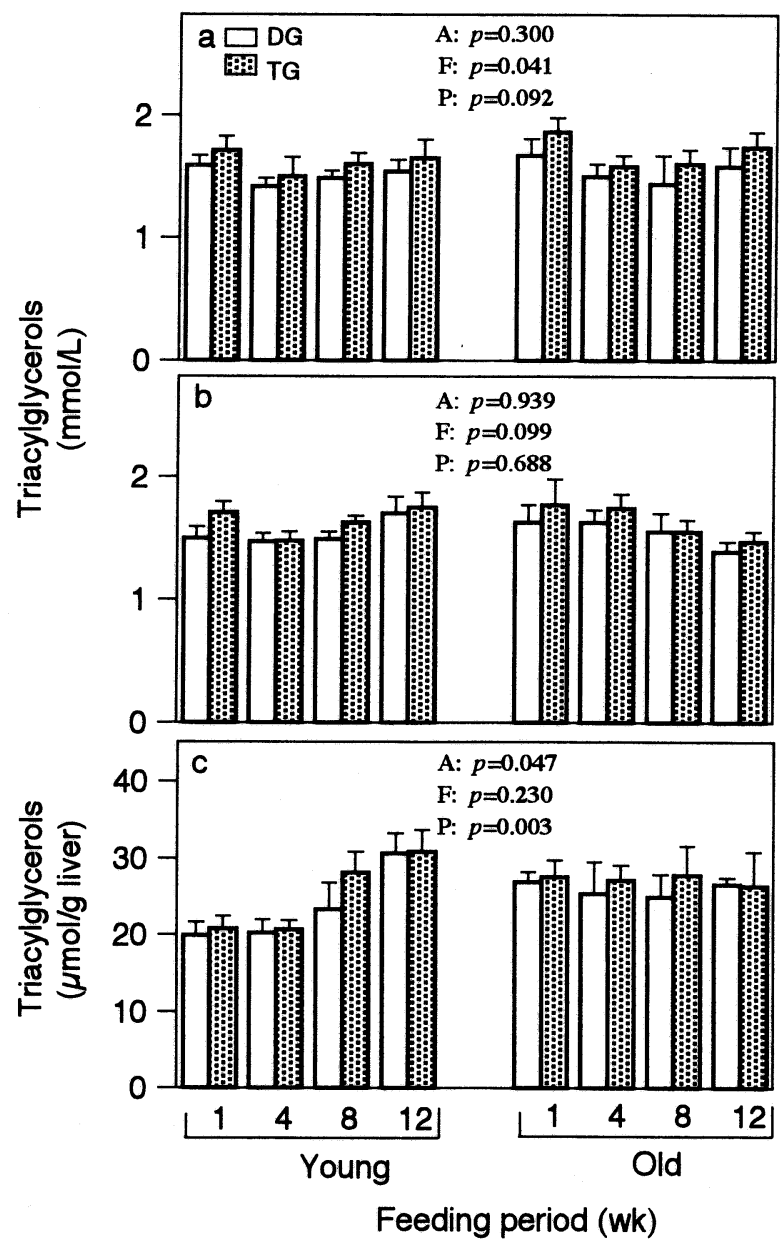

Fig. 3. Effects of dietary fat types on the plasma and liver triacylglycerol concentrations of young and old rats. The plasma and liver triacylglycerol concentrations of the same rats to Fig. 1 are shown. Plasma triacylglycerol concentrations of the portal vein (panel a) and inferior vena cava (panel b), and liver triacylglycerol concentrations (panel c) are shown. Data are means \pm SE, $n=6$. Three-way ANOVA in each panel, A, aging main effect; $F$, dietary fat main effect; P, feeding period main effect. No significant difference was found between DG oil and TG oil groups by $t$-test. 
vena cava were not significantly different due to dietary oil in the young and old rats fed for $1,4,8$, and $12 \mathrm{wk}$, whereas the concentrations in portal veins were rather lower in rats fed DG oil. The results are shown in Fig. 3. Liver triacylglycerol concentrations were not significantly different due to dietary oil in young and old rats.

Liver acetyl-CoA carboxylase and fatty acid synthase activities were not significantly different due to dietary oil in young and old rats fed for 1,4 , and 8 wk. For example, at $4 \mathrm{wk}$ after the feeding, liver acetyl-CoA carboxylase activities were $(\mathrm{mU} / \mathrm{mg}$ protein, mean values \pm SE, $n=6) 4.73 \pm 0.61$ and $4.63 \pm 0.66$ in the DG and TG oil groups, respectively, of the young rats, and 3.82 \pm 0.47 and 3.95 \pm 0.31 , respectively, in the old rats. Liver fatty acid synthase activities were $(\mathrm{mU} / \mathrm{mg}$

Table 2. Effects of dietary fat types on incremental values of plasma glucose and insulin concentrations in glucose tolerance test. ${ }^{1}$

\begin{tabular}{|c|c|c|}
\hline \multirow{2}{*}{$\begin{array}{c}\text { Feeding period } \\
\text { Dietary fat }\end{array}$} & \multicolumn{2}{|c|}{ Increments from basal levels ${ }^{2}$} \\
\hline & $\begin{array}{c}\text { Glucose area } \\
\mathrm{mmol} /(\mathrm{L} \cdot 2 \mathrm{~h})\end{array}$ & $\begin{array}{c}\text { Insulin area } \\
\mathrm{pmol} /(\mathrm{L} \cdot 2 \mathrm{~h})\end{array}$ \\
\hline \multicolumn{3}{|l|}{ Young } \\
\hline \multicolumn{3}{|l|}{1 wk feeding } \\
\hline DG & $9.90 \pm 0.75$ & $159 \pm 10.8^{*}$ \\
\hline TG & $9.28 \pm 0.58$ & $120 \pm 10.8$ \\
\hline \multicolumn{3}{|l|}{3 wk feeding } \\
\hline DG & $10.2 \pm 0.84^{*}$ & $163 \pm 13.3^{*}$ \\
\hline TG & $7.58 \pm 0.40$ & $107 \pm 12.9$ \\
\hline \multicolumn{3}{|l|}{7 wk feeding } \\
\hline DG & $7.07 \pm 1.28$ & $140 \pm 16.4$ \\
\hline TG & $7.22 \pm 1.02$ & $120 \pm 14.6$ \\
\hline \multicolumn{3}{|l|}{ Old } \\
\hline \multicolumn{3}{|l|}{1 wk feeding } \\
\hline DG & $11.9 \pm 0.43^{*}$ & $185 \pm 14.1$ \\
\hline TG & $9.65 \pm 0.53$ & $177 \pm 21.6$ \\
\hline \multicolumn{3}{|l|}{3 wk feeding } \\
\hline DG & $7.77 \pm 0.75$ & $167 \pm 29.0$ \\
\hline TG & $6.39 \pm 0.53$ & $139 \pm 16.8$ \\
\hline \multicolumn{3}{|l|}{$7 \mathrm{wk}$ feeding } \\
\hline DG & $7.37 \pm 0.58^{*}$ & $215 \pm 35.4$ \\
\hline TG & $5.60 \pm 0.47$ & $201 \pm 35.2$ \\
\hline \multirow[t]{3}{*}{ ANOVA $^{3}$} & $\mathrm{~A}: p=0.363$ & $\mathrm{~A}: p=0.001$ \\
\hline & $\mathrm{F}: p=0.003$ & $\mathrm{~F}: p=0.044$ \\
\hline & $\mathrm{P}: p<0.001$ & $\mathrm{P}: p=0.306$ \\
\hline
\end{tabular}

${ }^{1}$ Data are presented as means \pm SE, $n=6$. The oral glucose tolerance test at 3 and $7 \mathrm{wk}$ feeding was done $1 \mathrm{wk}$ before the rats were sacrificed.

${ }^{2}$ Increments from basal levels of plasma glucose and insulin concentrations in the glucose tolerance test $(0$ to $2 \mathrm{~h})$ were calculated as: area $=(a+2 b+3 c+6 d+4 e) \times$ $1 / 8-2 a[\mathrm{mmol} /(\mathrm{L} \cdot 2 \mathrm{~h})$ or $\mathrm{pmol} /(\mathrm{L} \cdot 2 \mathrm{~h})]$, where $a$ represents the level of each index before oral glucose load, and $b, c, d$, and $e$ were the levels at $15,30,60$, and $120 \mathrm{~min}$ after glucose intubation, respectively.

${ }^{3}$ Three-way ANOVA: A, aging main effect; F, fat type main effect; $P$, feeding period main effect. * Significantly different from TG oil group ( $t$-test). protein) $0.61 \pm 0.13$ and $0.69 \pm 0.06$ in the DG and TG oil groups, respectively, of the young rats, and $0.71 \pm 0.15$ and $0.70 \pm 0.15$, respectively, in the old rats.

Effects of dietary fat typës on glucose tolerance test

The time courses for increments of the plasma glucose and insulin concentrations in response to an oral glucose load were followed. The increments of glucose and insulin values ( 0 to $2 \mathrm{~h}$ after glucose intubation)
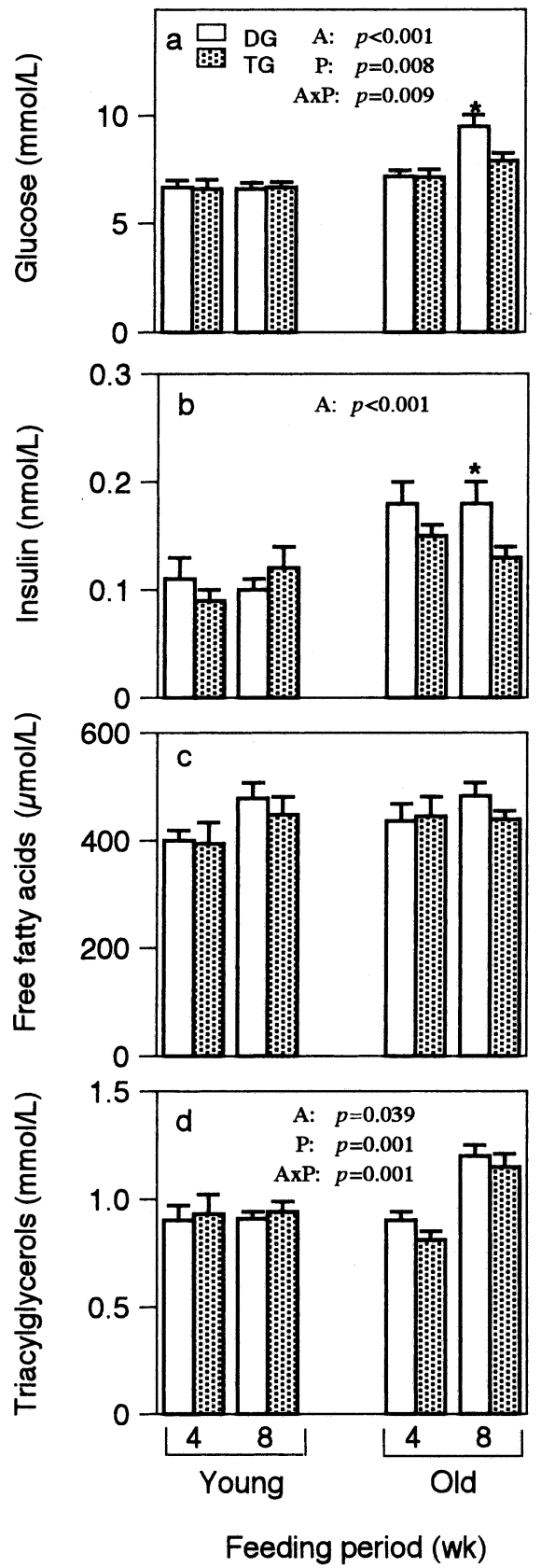

Fig. 4. Effects of dietary fat types on plasma glucose, insulin, free fatty acids and triacylglycerol concentrations in fasted rats. The rats fed diets containing $10 \%$ DG oil or TG oil for 4 or $8 \mathrm{wk}$ were fasted for $16 \mathrm{~h}$. These fasted rats were not the same ones used for other analyses. Blood was taken from the tail vein by heparinized syringe. Data are means $\pm \mathrm{SE}, n=6$. Threeway ANOVA in each item, $\mathrm{A}$, aging main effect; $\mathrm{F}$, dietary fat main effect; $P$, feeding period main effect. * Significantly different from TG oil group ( $t$-test). 
were calculated from the values and are shown in Table 2. In rats fed DG oil, the increments of glucose values were significantly higher than in those fed TG oil during the feeding period of 3 and $7 \mathrm{wk}$ in the young and old rats. The insulin increments were significantly higher in the DG oil than in the TG oil groups in the young rats, but were not in the old rats. The insulin increments were higher in the old rats than in the young.

Plasma glucose, insulin, fatty acid and triacylglycerol concentrations in fasted rats

The plasma glucose, insulin, fatty acid and triacylglycerol concentrations in the fasted rats after 4 and

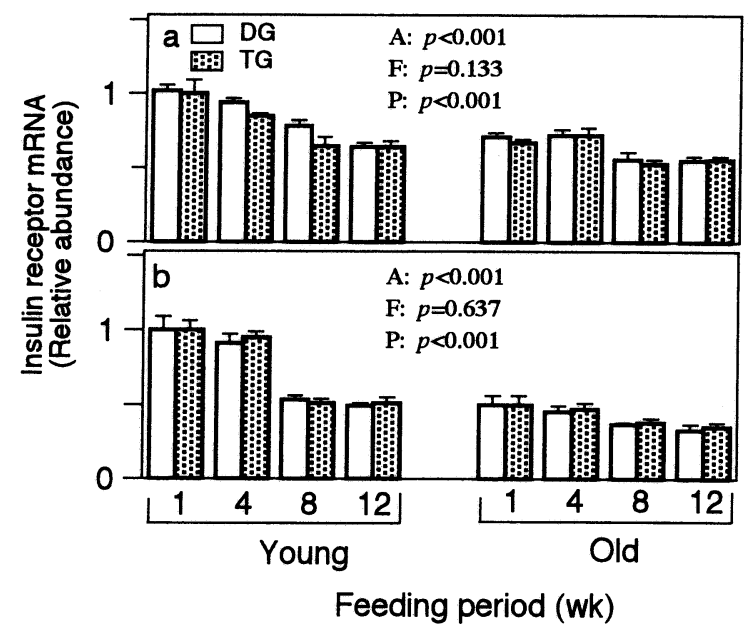

Fig. 5. Effects of dietary fat types on relative mRNA expressions of insulin receptors in young and old rats. The relative mRNA abundances of insulin receptors of the same rats to Fig. 1 are shown. The insulin receptor mRNA abundances in liver (panel a) and epididymal adipose tissues (panel b) are shown. The relative mRNA abundances were normalized to each in young rats fed the DG oil diet. Date are means $\pm S E, n=6$. Three-way ANOVA in each panel, A, aging main effect; $P$, feeding period main effect. No significant difference was found between DG oil and TG oil groups by $t$-test.
8 wk of feeding the DG or TG oil diets are shown in Fig. 4 . In the young rats, these concentrations were not significantly different in the diets and the feeding periods. In the old rats, however, the fasted glucose concentrations were significantly higher after $8 \mathrm{wk}$ of feeding than after $4 \mathrm{wk}$, and significantly higher in the rats fed DG oil diet than in those fed TG oil diet. The fasted insulin concentrations were also higher in the rats fed DG oil diet after $8 \mathrm{wk}$ of feeding. The fasted triacylglycerol concentrations were significantly higher after $8 \mathrm{wk}$ of feeding than after $4 \mathrm{wk}$, but not significantly different in both dietary oil groups.

Effects of dietary fat types on insulin receptor $m R N A$ expressions

The relative mRNA abundances of insulin receptor in rat livers and epididymal adipose tissues were measured. The relative densities normalized to the values of $18 \mathrm{~S}$ rRNA are shown in Fig. 5. The relative mRNA abundances of insulin receptors in the livers and adipose tissues were not significantly different in rats fed the DG and TG oil diets. However, the relative mRNA abundances of insulin receptors were reduced with feeding period, and in the old rats in comparison with the young rats.

Effects of dietary fat types on insulin binding to receptors

Insulin binding capacities to partially purified insulin receptors from livers and epididymal adipocytes of rats fed the DG oil and TG oil diets for $4 \mathrm{wk}$ are measured and shown in Table 3. The insulin binding capacities to the insulin receptors from livers were significantly lower in the young and old rats fed DG oil than in those fed TG oil. However, the insulin binding capacities in adipose tissues were not different between the dietary oil groups. The insulin binding capacities in both liver and adipose tissues were significantly reduced in the old rats as compared to the young rats. On the other hand, the insulin binding affinities to receptors from the livers and adipocytes were not altered by dietary oil. The binding affinities in the old rats were reduced in the liver compared with those in the young rats, but were not re-

Table 3. Effects of dietary fat types on binding capacity and affinity constant (high affinity sites) of purified insulin receptors in livers and white adipose tissue. ${ }^{1}$

\begin{tabular}{cccccc}
\hline \multirow{2}{*}{ Dietary fat } & \multicolumn{2}{c}{ Liver plasma membrane } & & \multicolumn{2}{c}{ Adipocytes } \\
\cline { 2 - 3 } \cline { 5 - 6 } & $\begin{array}{c}\text { Binding capacity } \\
(\mathrm{pmol} / \mathrm{mg} \text { protein })\end{array}$ & $\begin{array}{c}\text { Affinity } \\
\times 10^{-11}(\mathrm{~mol} / \mathrm{L})\end{array}$ & & $\begin{array}{c}\text { Binding capacity } \\
(\mathrm{pmol} / \mathrm{mg} \text { protein })\end{array}$ & $\begin{array}{c}\text { Affinity } \\
\times 10^{-11}(\mathrm{~mol} / \mathrm{L})\end{array}$ \\
\hline Young & & & & \\
DG & $64.9 \pm 6.42$ & $2.44 \pm 0.11$ & & $5.80 \pm 1.29$ & $0.59 \pm 0.04$ \\
TG & $85.9 \pm 8.38$ & $2.63 \pm 0.54$ & & $6.60 \pm 0.73$ & $0.55 \pm 0.01$ \\
Old & $28.2 \pm 1.43$ & $1.65 \pm 0.03$ & & $1.50 \pm 0.14$ & $0.61 \pm 0.01$ \\
DG & $56.5 \pm 9.21$ & $1.77 \pm 0.02$ & & $1.58 \pm 0.18$ & $0.59 \pm 0.01$ \\
TG & A: $p=0.002$ & A: $p=0.008$ & & A: $p=0.001$ & A: $p=0.074$ \\
ANOVA ${ }^{2}$ & F: $p=0.009$ & F: $p=0.559$ & F: $p=0.496$ & F: $p=0.102$
\end{tabular}

\footnotetext{
${ }^{1}$ These results were calculated from Scatchard plots. Data are means \pm SE, $n=3$. The young and old rats were fed DG or TG oil diets for $4 \mathrm{wk}$.

${ }^{2}$ Two-way ANOVA: A, aging main effect; $\mathrm{F}$, dietary fat main effect.
} 
duced in the adipose tissues.

\section{DISCUSSION}

Mansbach et al. (33) reported that $41 \%$ of the mass was recovered in the thoracic lymph on duodenal infusion of ${ }^{3} \mathrm{H}$-labeled glyceryl trioleate and $39 \%$ of the infused dpm was calculated to be transported into the portal vein. A similar amount of triacylglycerols appeared to be transported into the thoracic lymph and portal vein.

In the present study, the plasma triacylglycerol concentrations were significantly lower in the portal vein with dietary DG oil than with TG oil, and the plasma free fatty acid concentrations were significantly higher. In the inferior vena cava (after liver), however, the plasma triacylglycerol concentrations were not lower in rats fed DG oil any more, and the free fatty acid concentrations were still higher. Liver triacylglycerol concentrations also did not differ due to the dietary oil. The DG oil diet did not reduce the weights (per body weight) of epididymal and perirenal adipose tissue at any feeding period of 1-12 wk. Thus, the dietary DG oil did not appear to affect the lipid lowering effects in the tissues.

However, Watanabe et al. (1) reported that body fat ratio was significantly reduced in rats fed $10 \%$ (by weight) DG oil diet for 3 and $4 \mathrm{wk}$ as compared to TG oil diet. Further, intragastric infusion of an emulsion of DG oil reduced the serum triacylglycerol concentrations as compared to the TG oil infusion in rats. 1Monoacylglycerols, rarely seen in the digestion of TG oil in the intestine, were produced from DG oil and greater amounts of free fatty acids were transported into the portal vein after the administration of DG oil as compared to TG oil. They hypothesized that the reduction of fat accumulation by dietary DG oil is caused by the different metabolic fates after absorption into the gastrointestinal epithelial cells.

However, they did not demonstrate the effect of increased fatty acids on the reduction of fat accumulation. Moreover, the same group also reported that energy values of the DG oil and TG oil, measured by bomb calorimeter, were very similar and the apparent digestibility of the DG oil and TG oil were similar (96\%) (5). Thus, their group did not demonstrate the hypothesis.

In the present experiment, however, such lipid-lowering effects of DG oil were not found in rats fed a 10\% (by weight, $22 \%$ by calories) DG oil diet for $1-12 \mathrm{wk}$. They did not describe about paired-feeding between the DG and TG oil groups (1). As dietary energy and nutrient compositions greatly influence the lipid lowering effects, paired-feeding is important in this kind of experiment.

They reported also that, in healthy males, body weight, body mass index, and waist circumference were decreased by the intake of $10 \mathrm{~g} / \mathrm{d}$ (4.9\% DG oil of total calories) of DG oil for $16 \mathrm{wk}$ as compared to the controls of TG oil (4). Total fat, visceral fat area, and subcutaneous fat area of the abdominal traverse images of computed tomography were also reduced by dietary DG oil.
Yamamoto et al. (34) reported that the serum concentrations of triacylglycerol and glycohemogloblin A1C were reduced by substituting DG oil $(10 \mathrm{~g} / \mathrm{d})$ for TG cooking oil for $12 \mathrm{wk}$ in diabetic subjects at the out-patient clinic, whereas the glucose concentrations were not reduced. They did not show the serum free fatty acid and insulin concentrations.

The plasma free fatty acid concentrations were significantly elevated by dietary DG oil as compared to TG oil in both the portal vein and inferior vena cava of the young and old rats. The free fatty acid concentrations were more elevated in the portal vein. Moreover, plasma concentrations of total ketone bodies in the inferior vena cava were also elevated by DG oil, particularly at $4 \mathrm{wk}$ of feeding. It is suggested that the increased plasma free fatty acids due to dietary DG oil were transported to the liver via the hepatic portal vein and the capacity of free fatty acid oxidation in the liver was exceeded.

Increased plasma free fatty acid concentrations have commonly been associated with impaired insulin-mediated glucose uptake and with many insulin-resistant states $(6,7)$. Fatty acid-rich medium reduced insulin receptor tyrosin kinase activity in rat hepatoma cells (8). Dresner et al. (9) concluded that increased concentrations of plasma free fatty acids induce insulin resistance in humans through the inhibition of glucose transport activity, probably as a consequence of decreased IRS-1associated PI 3-kinase activity. Griffin et al. (35) reported that increased insulin resistance was associated with abnormalities in the insulin-signaling cascade and may be mediated by the free fatty acid activation of protein kinase $\mathrm{C} \theta$.

We have found that insulin binding capacities to the insulin receptors from the liver were lower in rats fed DG oil than in those fed TG oil, whereas insulin receptor mRNA expressions were not significantly different. The elevated ambient free fatty acid levels are associated with impaired insulin cell surface binding to isolated hepatocytes, possibly through an effect of lipid oxidation on the internalization/recycling of the insulin receptor complex (36). Thus, the present results suggest that increased plasma free fatty acids in rats fed DG oil suppressed the insulin binding activities. The insulin binding activities and the receptor expressions were reduced in the old rats. It is suggested that insulin resistance may be stimulated in the old rats.

It is well known that polyunsaturated fatty acids suppress fatty acid synthesis and then triacylglycerol levels. DG and TG oil used contained about 54\% and $40 \%$ polyunsaturated fatty acids, respectively, as described in Materials and Methods. However, the difference of polyunsaturated fatty acid content in the 10\% DG and TG oil diets did not affect the enzyme activities of acetylCoA carboxylase and fatty acid synthase (shown in the results) and the plasma, liver triacylglycerol concentrations (not shown but in Ref. 37). Dietary polyunsaturated fatty acids suppressed them in a dose-dependent manner at the lower levels of polyunsaturated fatty acids (37). Therefore, the difference in polyunsaturated 
fatty acid percent of DG and TG oil is worth little consideration in these present experiments.

Soni et al. (38) reported that compared to the control (fed edible TG oil at $5.3 \%$, by weight), there was a significant increase in the number of females fed DG oil at $5.3 \%$ with either benign or malignant epithelial mammary gland neoplasms. However, they concluded that these changes were not considered biologically significant, because the tumor incidence was not similar in two control groups (fed edible oil at $1.7 \%$ and $5.3 \%$ ) and were not dose related. They did not note any other DG oil-related effects on clinical signs. However, a chronic study at higher DG oil and total fat levels in diets may be important for health safety.

Thus, the dietary DG oil did not reduce the body weights, epididymal and perirenal adipose tissue weights in both young and old rats in the present study. Neither did the DG oil reduce the plasma (except in portal vein) and liver triacylglycerol levels. The DG oil elevated the plasma glucose and free fatty acid concentrations as compared to TG oil in these rats. Particularly in the old rats, the DG oil elevated the fasted plasma glucose and insulin concentrations after longer feeding, suggesting that glucose intolerance might be induced by dietary DG oil. It is generally accepted that there are several differences between human and rat in nutritional response. Further studies on health safety of DG oil (containing such a high level of DG, $80 \%$ in total) should be investigated particularly in the case of considerable amount ingestion of the DG oil as daily food in elderly humans with higher plasma glucose levels.

\section{Acknowledgments}

This work was supported by Tezukayama Gakuin University (Japan).

\section{REFERENCES}

1) Watanabe H, Onizawa K, Taguchi H, Kobori M, Chiba H, Naito S, Matsuo N, Yasukawa T, Hattori M, Shimasaki H. 1997. Nutritional characterization of diacylglycerols in rats. J Jpn Oil Chem Soc 46: 301-307.

2) Watanabe H, Onizawa K, Taguchi H, Fujimori N, Naito S, Gotoh N, Yasukawa T, Hattori M, Shimasaki H. 1997. Effects of diacylglycerols on lipid metabolism in human. J Jpn Oil Chem Soc 46: 309-314.

3) Watanabe H, Nagao T, Gotoh N, Fukushima Y, Onizawa K, Taguchi H, Ohmachi T, Yasukawa T, Naito S, Shimasaki H, Itakura H. 1998. Long-term effects of dietary diacylglycerols on body fat metabolism. J Jpn Oil Chem Soc 47: 369-376.

4) Nagao T, Watanabe H, Goto N, Onizawa K, Taguchi H, Matsuo N, Yasukawa T, Tsushima R, Shimasaki H, Itakura H. 2000. Dietary diacylglycerol suppresses accumulation of body fat compared to triacylglycerol in men in a double-blind controlled trial. J Nutr 130: 792-797.

5) Taguchi H, Nagao T, Watanabe H, Onizawa K, Matsuo N, Tokimitsu I, Itakura H. 2001. Energy value and digestibility of dietary oil containing mainly 1,3-diacylglycerol are similar to those of triacylglycerol. Lipids $\mathbf{3 6}$ : 379-382.

6) Frayn KN. 1993. Insulin resistance and lipid metabo- lism. Curr Opin Lipidol 4: 197-204.

7) Steiner G, Morita S, Vranic M. 1980. Resistance to insulin but not to glucagons in lean human hypertrigliceridemics. Diabetes 29: 899-905.

8) Hubert P, Bruneau-Wack C, Cremel G, LeMarchandBrustel Y, Staedel C. 1991. Lipid-induced insulin resistance in cultured hepatoma cells is associated with a decreased insulin receptor tyrosin kinase activity. Cell Regul 2: 65-72.

9) Dresner A, Laurent D, Marcucci M, Griffin ME, Dufour S, Cline GW, Slezak LA, Andersen DK, Hundal RS, Rothman DL, Peterson KF, Shulman GI. 1999. Effects of free fatty acids on glucose transport and IRS-1-associated phosphatidylinositol 3-kinase activity. J Clin Invest 103: 253-259.

10) Crossley A, Freeman IP, Hudson JF, Pierce JH. 1959. Acyl migration in diglycerides. J Chem Soc 760-764.

11) Reeves PG, Nielsen FH, Fahey GC Jr. 1993. Purified diets for laboratory rodents: final report of the American Institute of Nutrition ad hoc writing committee on the reformation of the AIN-76A rodent diet. $J$ Nutr 123: 1939-1951.

12) National Research Council. 1985. Guide for the Care and Use of Laboratory Animals. Publication No. 85-23 (rev.). National Institute of Health, Bethesda, MD.

13) Ebina Y, Ellis L, Jamagin K, Edery M, Graf L, Clauser E, Ou J-H, Masiartz F, Kan YW, Goldfine ID, Roth RA, Rutter W. 1985. The human insulin receptor cDNA: the structural basis for hormone-activated transmembrane signaling. Cell 40: 747-758.

14) Chomczynski P, Sacchi N. 1987. Single-step method of RNA isolation by acid guanidium thiocyanate-phenolchloroform extraction. Anal Biochem 163: 156-159.

15) Katsurada A, Iritani N, Fukuda H, Matsumura $Y$, Nishimoto N, Noguchi T, Tanaka T. 1990. Effects of nutrients and hormones on transcriptional and post-transcriptional regulation of fatty acid synthase in rat liver. Eur J Biochem 190: 427-433.

16) Gonzales FJ, Kasper CB. 1982. Cloning of DNA complementary to rat liver NADPH-cytochrome $c$ (P-450) oxidoreductase and cytochrome P-450b mRNAs. J Biol Chem 257: 5962-5968.

17) Thomas PS. 1980. Hybridization of denatured RNA and small DNA fragments transferred to nitrocellulose. Proc Natl Acad Sci USA 77: 5201-5205.

18) Iritani N, Sugimoto T, Fukuda H. 2000. Gene expressions of leptin, insulin receptors and lipogenic enzymes are coordinately regulated by insulin and dietary fat in rats. J Nutr 130: 1183-1188.

19) Rodbel M. 1964. Metabolism of isolated fat cells. 1. Effects of hormones on glucose metabolism and lypolysis. J Biol Chem 239: 375-380.

20) Gammeltoft S, Gliemann J. 1973. Binding and degradation of ${ }^{125}$ I-labelled insulin by isolated fat cells. Biochim Biophys Acta 320: 16-32.

21) Olefsky JM, Reaven GM. 1975. Effects of age and obesity on insulin binding to isolated adipocytes. Endocrinology 96: 1486-1498.

22) Kadowaki T, Kasuga M, Akanuma Y, Ezaki O, Takaku F. 1984. Decreased autophosphorylation of the insulin receptor-kinase in streptozotocin-diabetic rats. $J$ Biol Chem 259: 14208-14216.

23) Hedo JA, Harison LC, Roth J. 1981. Binding of insulin receptors to lectins: evidence for common carbohydrate determinations on several membrane receptors. 
Biochemistry 20: 3385-3393.

24) Werner W, Rey H-G, Wielinger H. 1970. Uber die Eigenschaften eves neuen Chromogens fur die Blutzucherbestimmung nach der GOD/POD-Methode. Anal Chem 252: 224-228.

25) Morgan CR, Lazarow A. 1963. Immunoassay of insulin: Two antibody system plasma insulin levels of normal, subdiabetic and diabetic rats. Diabetes 12: $115-126$.

26) Fletcher MJ. 1968. A calorimetric method for estimating serum triglycerides. Clin Chim Acta 22: 393-397.

27) Kushiro H, Fukui I. 1971. Quantitation of free fatty acid. Clin Chem 1: 42-51.

28) Harano Y, Kosugi K, Hyosu T, Ueno S, Ichikawa Y, Shigeta Y. 1983. Sensitive and simplified method for the differential determination of serum levels of ketone bodies. Clin Chim Acta 134: 327-336.

29) Nakanishi S, Numa S. 1970. Purification of rat liver acetyl coenzyme A carboxylase and immunochemical studies on its synthesis and degradation. Eur J Biochem 16: $161-173$.

30) Hsu RY, Butterworth PHW, Porte JW. 1969. Pigeon liver fatty acid synthetase. Methods Enzymol 14: 233-239.

31) Lowry OH, Rosebrogh NJ, Faar AL, Randall RJ. 1951. Protein measurement with the phenol reagent. J Biol Chem 237: 3233-3239.

32) Snedecor GW, Cocharan WG. 1967. Statistical
Methods, p 285-338. Iowa State University Press, Ames, IA.

33) Mansbach CM II, Dowell RF, Pritchett D. 1991. Portal transport of absorbed lipids in rats. Am J Physiol 261 (3Pt): G530-538.

34) Yamamoto K, Asakawa H, Tokunaga K, Watanabe H, Matsuo N, Tokimitsu I, Yagi N. 2001. Long-term ingestion of dietary diacylglycerol lowers serum triacylglycerols in Type II diabetic patients with hypertriglyceridemia. J Nutr 131: 3204-3207.

35) Griffin ME, Marcucci MJ, Cline GW, Bell K, Barucci N, Lee D, Goodyear LJ, Kraegen EW, White MF, Shulman GI. 1999. Free fatty acid-induced insulin resistance is associated with activation of protein kinase $\mathrm{C}$ theta and alterations in the insulin signaling cascade. Diabetes 48: $1270-1274$.

36) Svedberg J, Biorntorp P, Smith U, Lonnroth P. 1992. Effect of free fatty acids on insulin receptor binding and tyrosine kinase activity in hepatocytes isolated from lean and obese rats. Diabetes 41: 294-298.

37) Iritani N, Kimura T, Fukuda H, Sugimoto T. 2000. Effects of dietary fatty acid on tissue fatty acid compositions in rats. J Jpn Soc Nutr Food Sci 53: 249-257.

38) Soni MG, Kimura H, Burdock GA. 2001. Chronic study of diacylglycerol in rats. Food Chem Toxicol 39: 317-329. 